\title{
Article
}

\section{The Effects of Antioxidant Supplements on the Inflammatory Gene Expression of Osteoarthritis-Like Chondrocytes}

\author{
Chen-Ying Su ${ }^{1,+}$, Yongxiang Luo ${ }^{2,+}$, Chi-Hau Fang ${ }^{1}$ and Hsu-Wei Fang ${ }^{1,3, *}$ \\ 1 Department of Chemical Engineering and Biotechnology, National Taipei University of Technology, \\ No. 1, Sec. 3, Zhongxiao E. Rd., Taipei 10608, Taiwan; chenying.su@mail.ntut.edu.tw (C.-Y.S.); \\ fangchihau@pidc.org.tw (C.-H.F.) \\ 2 Guangdong Key Laboratory for Biomedical Measurements and Ultrasound Imaging, \\ School of Biomedical Engineering, Shenzhen University, No. 3688, Nanhai Road, Nanshan District, \\ Shenzhen 518060, China; luoyongxiang@szu.edu.cn \\ 3 Institute of Biomedical Engineering and Nanomedicine, National Health Research Institutes, \\ No. 35, Keyan Road, Zhunan Town, Miaoli County 35053, Taiwan \\ * Correspondence: hwfang@ntut.edu.tw \\ + These authors contributed to this work equally.
}

Citation: Su, C.-Y.; Luo, Y.; Fang, C.-H.; Fang, H.-W. The Effects of Antioxidant Supplements on the Inflammatory Gene Expression of OsteoarthritisLike Chondrocytes. Appl. Sci. 2021, 11, 239. https://doi.org/10.3390/ app11010239

Received: 1 December 2020 Accepted: 24 December 2020 Published: 29 December 2020

Publisher's Note: MDPI stays neutral with regard to jurisdictional claims in published maps and institutional affiliations.

Copyright: (c) 2020 by the authors. Licensee MDPI, Basel, Switzerland. This article is an open access article distributed under the terms and conditions of the Creative Commons Attribution (CC BY) license (https: / / creativecommons.org/ licenses/by/4.0/).

\begin{abstract}
Osteoarthritis patients often experience pain and inflammation in joints. To understand whether antioxidant supplements could reduce inflammation and could potentially be applied for osteoarthritis treatment, vitamin E and resveratrol were investigated in this study. Hydrogen peroxide was used for inducing inflammation in porcine chondrocytes, and the lumen density was measured for the level of oxygen-derived free radicals. In total, 5, 50, 100, and $200 \mu \mathrm{M}$ of vitamin $\mathrm{E}$ and resveratrol were analyzed for cell viability and the effect of lumen density. In addition, the expressions of IL-1 $\beta$, TNF- $\alpha$, MMP-1, MMP-13, and COL2A1 were investigated when treating chondrocytes with $100 \mu \mathrm{M}$ vitamin E, $5 \mu \mathrm{M}$ resveratrol, or their combination before or after hydrogen peroxide induction. Inducing chondrocytes with hydrogen peroxide for $30 \mathrm{~min}$ increased the level of lumen density sufficiently and stimulated the expression of inflammatory genes. All the concentrations of vitamin E and resveratrol showed good cell viability. Single treatment with either vitamin E or resveratrol reduced inflammatory gene expression, and combined treatment increased the expression of collagen type II. The results suggested that post-treatment with both vitamin $\mathrm{E}$ and resveratrol has a better effect on the reduction in inflammation in osteoarthritis-like chondrocytes.
\end{abstract}

Keywords: antioxidant supplement; osteoarthritis; inflammation; vitamin E; resveratrol

\section{Introduction}

The prevalence of osteoarthritis (OA) increases with age, and its economic burden rises with the aging population in most countries [1]. OA causes disability because patients encounter pain and inflammation in the joints and, unfortunately, there is no cure. OA patients can only exercise for better mobility or take nonsteroidal anti-inflammatory drugs (NSAIDs) for temporary pain relief [2-4]. OA occurs with progressive changes in the production and functions of various cytokines, resulting in the inflammation and cartilage destruction of the joints [5]. It has been shown that OA patients have an increased level of interleukin-1 beta (IL-1 $\beta$ ) and tumor necrosis factor alpha (TNF- $\alpha$ ), and blocking the expression or activity of IL- $1 \beta$ and TNF- $\alpha$ can prevent chondrocytes from being damaged, resulting in a reduction in inflammation in animals [6,7]. IL-1 $\beta$ and TNF- $\alpha$ also interfere with the synthesis of collagen type II and aggrecan, which are key components of the cartilage matrix, resulting in a gradual loss of articular cartilage [8,9]. In addition, an upregulation of the matrix metalloproteases MMP-1, MMP-3, and MMP-13 is induced by IL-1 $\beta$ and TNF- $\alpha$ in OA, resulting in a degradation of the cartilage extracellular matrix [10].

IL-1 $\beta$ and TNF- $\alpha$ play roles cartilage damage not only through reducing the cartilage matrix but also through the stimulation of oxidative stress [1]. Oxidative stress measures 
the overall status of reactive oxygen species, including oxidants such as peroxides, superoxides, hydroxyl radicals, and peroxynitrites [11,12]. In OA patients, the oxidative stress index is higher [13]. It has been shown that oxidative stress down-regulates prolidase and up-regulates lipid peroxidation, resulting in the reduction in collagen type II synthesis and cartilage damage $[1,13,14]$. Therefore, intake of food and vitamins that can function as antioxidant supplements has been considered beneficial for reducing oxidative stress.

Two antioxidant supplements, vitamin E and resveratrol, were investigated in this study. Porcine chondrocytes were induced to mimic OA cells using hydrogen peroxide $\left(\mathrm{H}_{2} \mathrm{O}_{2}\right)$, and the inflammatory gene expression in the OA-like chondrocytes was examined. Different concentrations of vitamin $\mathrm{E}$ and resveratrol were tested for cell viability and for reducing the level of $\mathrm{H}_{2} \mathrm{O}_{2}$-derived free radicals. The effects of vitamin $\mathrm{E}$ and resveratrol on inflammatory gene expression before or after the chondrocytes were induced by $\mathrm{H}_{2} \mathrm{O}_{2}$ were analyzed to understand how vitamin $\mathrm{E}$ and resveratrol affect inflammatory gene expression in OA.

\section{Materials and Methods}

\subsection{Establishment of Osteoarthritis (OA)-Like Chondrocyte Cell Model}

The isolation of chondrocyte cells was previously described [15]. In brief, fresh porcine knees were purchased from a local market and sanitized with iodine. Full-thickness articular cartilage was harvested and cut into small pieces in Dulbecco's phosphate-buffered saline (DPBS, GIBCO, Thermo Fisher Scientific Inc., Waltham, MA, USA), and $0.2 \%$ of collagenase type I (Sigma, St. Louis, MO, USA) was mixed with the cartilage pieces and digested at $37^{\circ} \mathrm{C}$ for $18 \mathrm{~h}$ to obtain chondrocytes. After digestion, the chondrocytes were filtered through a 100 micron nylon mesh and washed in DPBS. The chondrocytes were cultured in $10 \mathrm{~mL}$ Dulbecco's modified Eagle medium (DMEM, GIBCO) containing $10 \%$ fetal bovine serum (FBS, GIBCO) and 1\% antibiotic-antimycotic solution (Sigma) at a density of $1 \times 10^{5}$ cells/well at $37^{\circ} \mathrm{C}$ in a $5 \% \mathrm{CO}_{2}$ incubator. After $24 \mathrm{~h}$, the culture medium was replaced with DMEM and the chondrocytes were cultured for another $18 \mathrm{~h}$.

Hydrogen peroxide was used to induce oxygen-derived free radicals and create OAlike cell models [16]. We added $100 \mu \mathrm{M} \mathrm{H}_{2} \mathrm{O}_{2}$ to the chondrocytes for $30 \mathrm{~min}$ or $2 \mathrm{~h}$ for induction. After the induction, $100 \mu \mathrm{L}$ supernatant was transferred to a well in a 96-well plate, and $100 \mu \mathrm{L} 0.004 \%$ luminol was added and incubated for $20 \mathrm{~min}$. The samples were then read by an enzyme-linked immunosorbent assay (ELISA) reader with wavelengths from 320 to $740 \mathrm{~nm}$ to obtain the lumen density. Each induction was repeated three times.

\subsection{Cell Viability Analysis}

L929 cells (mouse fibroblasts, Food Industry Research and Development Institute, strain number BCRC 60,091 ) were plated on a 96-well culture plate at a density of $1 \times 10^{5}$ cells/well in culture medium at $37^{\circ} \mathrm{C}$ overnight. After removing the culture medium the next day, $5,50,100$, or $200 \mu \mathrm{M}$ of vitamin E (Sigma) or resveratrol (Sigma) was added and cultured for 1, 2, or 3 days. A Cell Counting Kit-8 (CCK-8, Sigma) solution was then added into the medium, and the cells were incubated at $37^{\circ} \mathrm{C}$ for $1 \mathrm{~h}$. The samples were read by an ELISA reader with a wavelength of $650 \mathrm{~nm}$ to obtain the optical density (O.D.) values. The OD values of each group were averaged and divided by the averaged OD value of the control to obtain the percentage of cell viability. Each concentration was repeated four times.

\subsection{Inflammatory Gene Expression Analysis}

In the pre-treatment groups, the chondrocytes were treated with $100 \mu \mathrm{M}$ of vitamin $\mathrm{E}$ and/or $5 \mu \mathrm{M}$ of resveratrol for $2 \mathrm{~h}$ and then induced by $\mathrm{H}_{2} \mathrm{O}_{2}$ for $30 \mathrm{~min}$. In the posttreatment groups, the chondrocytes were induced by $\mathrm{H}_{2} \mathrm{O}_{2}$ for 30 min and treated with $100 \mu \mathrm{M}$ of vitamin E and/or $5 \mu \mathrm{M}$ of resveratrol for $2 \mathrm{~h}$. After treatment, Trizol was mixed with cells incubated on ice for $1 \mathrm{~h}$. Chloroform was added and vortexed, and the cells were centrifuged at 14,000 rpm (revolutions per minute) for $30 \mathrm{~min}$. The supernatant was transferred to a new tube, and the same volume of isopropanol was added and mixed 
gently. After centrifuging, the pallet was rinsed with $75 \%$ ethanol and resuspended in diethyl pyrocarbonate (DEPC) water (Thermo Fisher Scientific Inc.). The single-stranded cDNA was obtained by reverse transcription of RNA using a high-capacity cDNA reverse transcription kit (ABI Biosystems, Thermo Fisher Scientific Inc.). Gene expression analysis was conducted using the ABI Step-One Plus Real-Time PCR system. TaqMan ${ }^{\circledR}$ probes (ABI Biosystems) were used to measure the following genes: glyceraldehydes-3-phosphate dehydrogenase (GAPDH; Ss03375435_u1), interleukin 1 beta (Ss03393804_m1), tumor necrosis factor alpha (Ss03391317), matrix metalloproteinase-1 (Ss03374796), MMP-13 (Ss03373279), and type II collagen (COL2A1; Ss03373342). The $2^{-\Delta \Delta C t}$ method was employed to calculate the relative expression of each target gene. Each gene expression was tested three times.

\subsection{Statistical Analysis}

Differences in lumen density, cell viability, and gene expression between different treatments were assessed by Student's $t$-test to make allowance for comparisons. A $p$-value $<0.05$ was considered statistically significant.

\section{Results}

\subsection{Inflammation Gene Expression of OA-Like Cells}

When the chondrocytes were induced by $\mathrm{H}_{2} \mathrm{O}_{2}$ for $30 \mathrm{~min}$, the lumen density increased significantly compared to that of the cells without induction (Figure 1A). Although the lumen density also increased after the chondrocytes were induced for $2 \mathrm{~h}$, it was much lower than for $30 \mathrm{~min}$ induction (Figure 1A). The gene expression results showed that the expressions of IL-1, TNF- $\alpha$, and COL2A1 were higher when the chondrocytes were induced by $\mathrm{H}_{2} \mathrm{O}_{2}$ for $30 \mathrm{~min}$ than for $2 \mathrm{~h}$, although there was no significant difference (Figure 1B). In contrast, the expressions of MMP-1 and MMP-13 were higher when the cells were induced for $2 \mathrm{~h}$ (Figure 1B). Compared with no induction, the expressions of IL-1, TNF- $\alpha$, and COL2A1 increased when treated with $\mathrm{H}_{2} \mathrm{O}_{2}$ for $30 \mathrm{~min}$, but the IL-1 and TNF- $\alpha$ expressions decreased when induced by $\mathrm{H}_{2} \mathrm{O}_{2}$ for $2 \mathrm{~h}$ (Figure 1B). Therefore, $\mathrm{H}_{2} \mathrm{O}_{2}$ induction for $30 \mathrm{~min}$ was efficient for the chondrocytes to become OA-like cells.
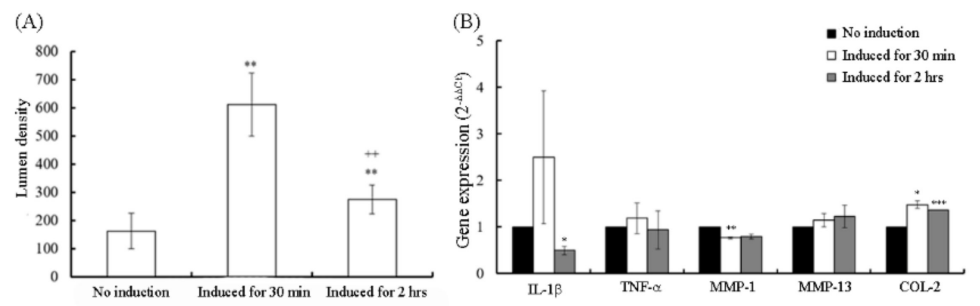

Figure 1. The induction of osteoarthritis by $\mathrm{H}_{2} \mathrm{O}_{2}$ in porcine chondrocytes. (A) The level of oxygenderived free radicals was represented by the level of lumen density. The level of lumen density increased significantly when the chondrocytes were treated with $\mathrm{H}_{2} \mathrm{O}_{2}$ for 30 min and $2 \mathrm{~h}$. ${ }^{* *} p<0.01$ compared with no induction. ${ }^{++} p<0.01$ compared with $30 \mathrm{~min}$ induction. (B) The expressions of IL-1 $\beta$, TNF- $\alpha$, and COL2A1 were higher when the chondrocytes were induced by $\mathrm{H}_{2} \mathrm{O}_{2}$ for $30 \mathrm{~min}$ (white bars) than for $2 \mathrm{~h}$ (gray bars). Gene expression with no induction is shown in black bars. ${ }^{*} p<0.05,{ }^{* *} p<0.01$, and ${ }^{* * *} p<0.001$ compared with no induction.

\subsection{Cell Viability of Vitamin E and Resveratrol}

Before investigating the effect of vitamin $\mathrm{E}$ and resveratrol on the inflammatory gene expression of OA-like chondrocytes, the cell viability of different concentrations of vitamin $\mathrm{E}$ and resveratrol was analyzed. When L929 cells were cultured with vitamin E for 1, 2, or 3 days, the cell viability was higher than $90 \%$ regardless of the concentration (Figure $2 \mathrm{~A}$ ). Although the cell viability was higher when vitamin $\mathrm{E}$ concentration was higher, there was no significant difference compared with $5 \mu \mathrm{M}$ vitamin $\mathrm{E}$. When the cells were cultured with resveratrol, the cell viability was higher than $80 \%$, with no statistical differences among the 
different concentrations (Figure 2B). The concentrations of vitamin $\mathrm{E}$ and resveratrol tested in this study demonstrated good biocompatibility.
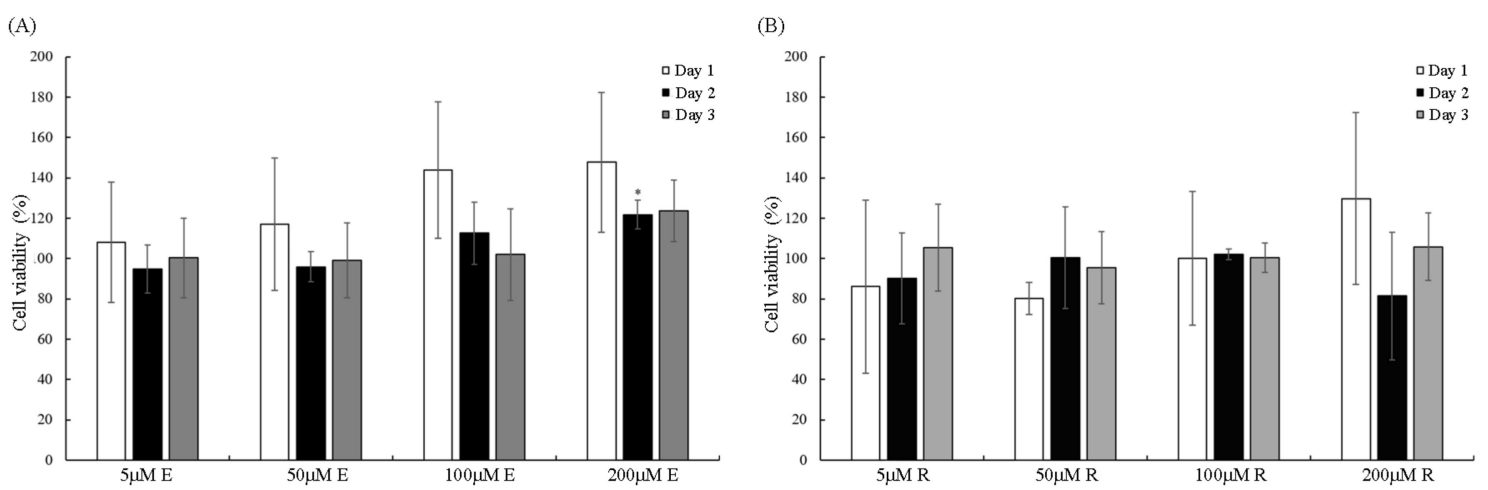

Figure 2. The cell viability of vitamin E and resveratrol at various concentrations. (A) L929 cells were cultured with 5 , 50, 100, or $200 \mu \mathrm{M}$ of vitamin E for 1 (white bars), 2 (black bars), or 3 (gray bars) days. The cell viability increased when the concentration of vitamin E was higher. ${ }^{*} p<0.05$ compared with the cell viability at $5 \mu \mathrm{M}$. (B) When the L929 cells were cultured with 5,50,100, and $200 \mu \mathrm{M}$ of resveratrol for 1 day, the cell viability increased depending on the concentration of resveratrol.

\subsection{Reduction in Lumen Density by Vitamin E and Resveratrol}

To investigate the role of vitamin $\mathrm{E}$ and resveratrol in reducing the free radicals induced by $\mathrm{H}_{2} \mathrm{O}_{2}$, different concentrations of vitamin $\mathrm{E}$ and resveratrol were treated with OA-like chondrocytes. The result showed that vitamin $\mathrm{E}$ significantly decreased the lumen density compared with $\mathrm{H}_{2} \mathrm{O}_{2}$ induction (Figure 3A). Among all the concentrations and treatment time intervals, adding $100 \mu \mathrm{M}$ of vitamin $\mathrm{E}$ after $\mathrm{H}_{2} \mathrm{O}_{2}$ induction resulted in the lowest lumen density. Similar results were observed when OA-like chondrocytes were treated with resveratrol (Figure 3B). Treating chondrocytes with $5 \mu \mathrm{M}$ of resveratrol before and after $\mathrm{H}_{2} \mathrm{O}_{2}$ induction demonstrated the lowest lumen density. Therefore, $100 \mu \mathrm{M}$ of vitamin $\mathrm{E}$ and $5 \mu \mathrm{M}$ of resveratrol were used for further gene expression analysis.
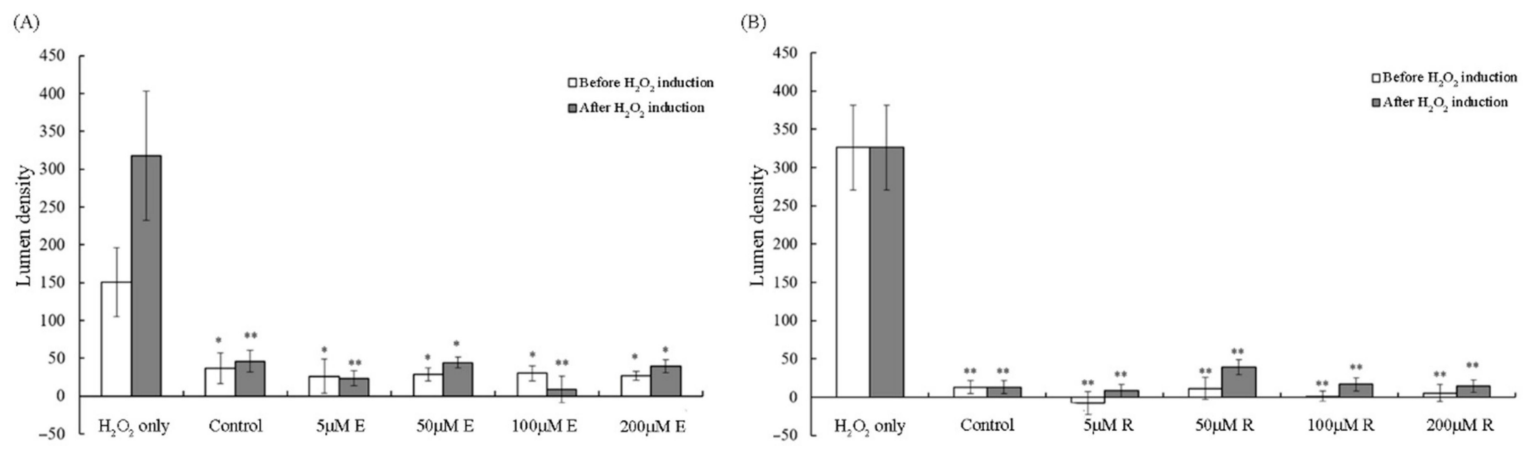

Figure 3. The changes in the level of lumen density when treating OA-like chondrocytes with vitamin $\mathrm{E}$ and resveratrol. Adding vitamin $\mathrm{E}$ (A) or resveratrol (B) at 5, 50, 100, and $200 \mu \mathrm{M}$ before $\mathrm{H}_{2} \mathrm{O}_{2}$ induction (white bars) or after $\mathrm{H}_{2} \mathrm{O}_{2}$ induction significantly reduces the level of lumen density. ${ }^{*} p<0.05$ and ${ }^{* *} p<0.01$ compared with $\mathrm{H}_{2} \mathrm{O}_{2}$ induction.

\subsection{The Effect of Vitamin E and Resveratrol on Inflammatory Gene Expression}

Figure 4 shows the results of gene expression. The high expression of IL- $1 \beta$ considerably decreased when OA-like chondrocytes were treated with vitamin $\mathrm{E}$ and resveratrol. The best reduction occurred when the chondrocytes were pre-treated with resveratrol, and pre-treated and post-treated with a combination of vitamin E and resveratrol. For TNF- $\alpha$ expression, post-treatment of vitamin $\mathrm{E}$ and/or resveratrol was better than pre-treatment. Post-treatment of resveratrol and the combination decreased MMP-1 expression compared 
with $\mathrm{H}_{2} \mathrm{O}_{2}$ induction, but only pre-treatment of vitamin $\mathrm{E}$ or resveratrol reduced the expression of MMP-13. In addition, the combination of vitamin $\mathrm{E}$ and resveratrol increased the expression of COL2A1 regardless of pre-treatment or post-treatment.

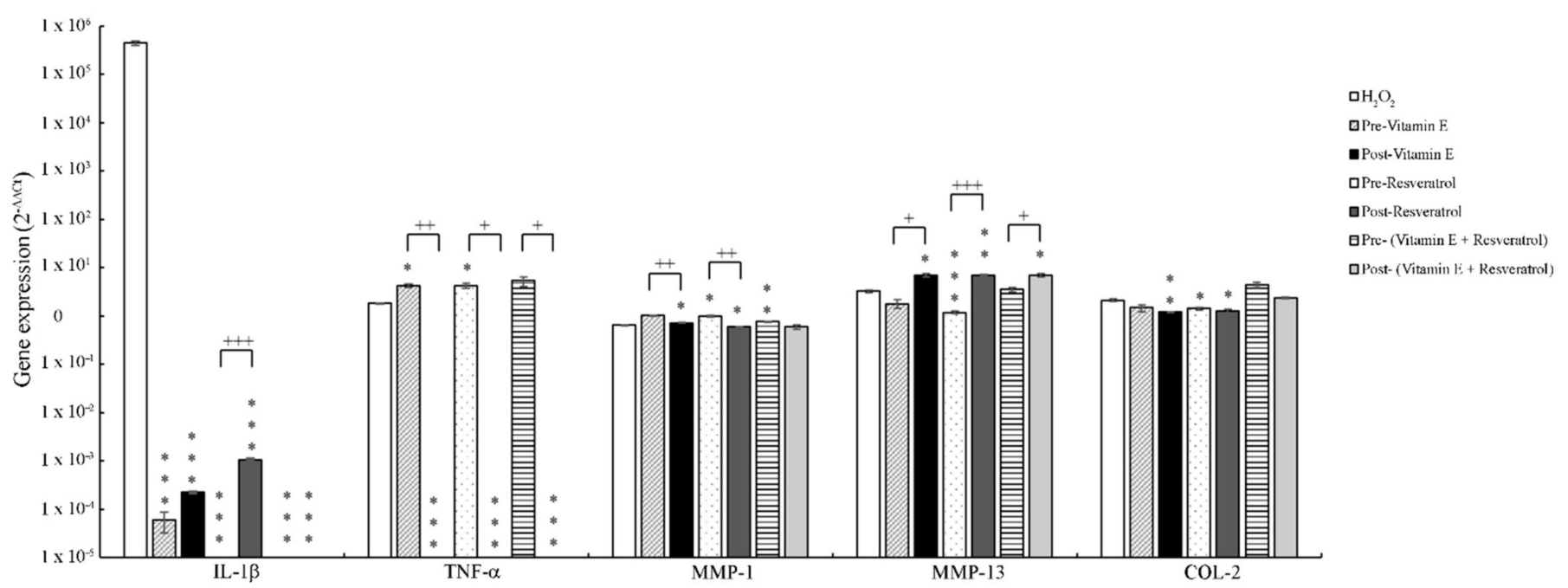

Figure 4. The inflammatory gene expression of OA-like chondrocytes when treated with vitamin E and resveratrol. The expressions of IL-1 $\beta$, TNF- $\alpha$, MMP-1, MMP-13, and COL2A1 when the chondrocytes were pre-treated with $100 \mu \mathrm{M}$ of vitamin $\mathrm{E}$ (gray slashed bars), $5 \mu \mathrm{M}$ of resveratrol (black bars), or their combination (dotted bars), or when the chondrocytes were post-treated with vitamin $\mathrm{E}$ (dark gray bars), resveratrol (horizonal striped bars), or their combination (light gray bars). ${ }^{*} p<0.05,{ }^{* *} p<0.01$, and ${ }^{* * *} p<0.001$ compared with $\mathrm{H}_{2} \mathrm{O}_{2}$ induction; ${ }^{+} p<0.05,{ }^{++} p<0.01$, and ${ }^{+++} p<0.001$.

\section{Discussion}

OA patients often describe pain and stiffness in the joints and are thus recommended NSAIDs, which have some anti-inflammatory and analgesic effects [17]. However, prolonged use of NSAIDs results in adverse renal, hepatic, and cardiovascular effects as well as economic burden [18]. Alternative strategies have been proposed, including taking antioxidant supplements, which may reduce oxidative stress and consequently inflammation and pain. Vitamin $\mathrm{E}$ has been shown to reduce free radicals by donating its hydrogen and to modulate the activity of a transcription factor that regulates the expression of antioxidant enzymes $[19,20]$. In the current study, pre-treatment and post-treatment of vitamin $E$ at $100 \mu \mathrm{M}$ effectively reduced the level of oxygen-derived free radicals (Figure 3A). Indeed, $100 \mu \mathrm{M}$ of vitamin E pre-treatment was shown to reverse oxidant-induced alterations in chondrocytes [21]. Our results also demonstrated that pre-treating chondrocytes with vitamin E reduces the expression of IL- $1 \beta$ and MMP-13. In contrast, post-treatment of vitamin E decreases IL-1 $\beta$ and TNF- $\alpha$ expression (Figure 4). However, treating chondrocytes with vitamin $\mathrm{E}$ before and after induction results in an increase in MMP-1 and a reduction in COL2A1. Our results suggested that although treating vitamin E in OA-like cells reduces the high expression of IL- $1 \beta$ and TNF- $\alpha$ induced by $\mathrm{H}_{2} \mathrm{O}_{2}$, it does not promote COL2A1 expression. Therefore, vitamin $\mathrm{E}$ might only play a role in reducing inflammation in OA-like chondrocytes by inhibiting the activity of IL-1 $\beta$.

In addition, our results showed that resveratrol reduces the level of $\mathrm{H}_{2} \mathrm{O}_{2}$-induced free radicals, especially at $5 \mu \mathrm{M}$ (Figure 2B). Resveratrol at $5 \mu \mathrm{M}$ also influenced the expression of inflammatory genes, and pre-treatment of resveratrol had different effects than post-treatment. Pre-treatment of resveratrol resulted in a complete inhibition of IL-1 $\beta$ and a reduction in MMP-13, while post-treatment led to a complete inhibition of TNF- $\alpha$ and a decrease in IL-1 $\beta$ and MMP-1 (Figure 4). Resveratrol has been demonstrated to suppress IL-1 $\beta$-induced proinflammatory and MMP production in cell culture models of OA [22-24]. Resveratrol also reduced cartilage tissue destruction in a rabbit model of OA [25]. Evidence shows that resveratrol is an activator of sirtuin 1 (SIRT 1), which plays a 
role in anti-inflammation along with other functions during OA progression [26]. In cell culture, resveratrol-activated SIRT 1 helps protect chondrocytes from IL-1 $\beta$-mediated oxidative stress [27]. Treating human chondrocytes with resveratrol could produce an antiinflammatory effect by affecting the TNF- $\alpha$-mediated pathway [28]. Therefore, resveratrol possibly reduces $\mathrm{H}_{2} \mathrm{O}_{2}$-induced free radicals and the expression of IL- $1 \beta$ (pre-treatment) and TNF- $\alpha$ (post-treatment) by activating SIRT1. The actual molecular mechanism of resveratrol in our OA-like chondrocyte model will need further investigation.

Many antioxidant supplements, such as curcumin or avocado-soya extract, have been shown to be of benefit in the prevention and/or management of OA [1]. However, the effects of different combinations of antioxidant supplements on OA have rarely been investigated. We combined $100 \mu \mathrm{M}$ vitamin $\mathrm{E}$ and $5 \mu \mathrm{M}$ resveratrol to investigate their effects. Our results showed that a combination of vitamin E and resveratrol completely blocks the expression of IL-1 $\beta$ and increases the expression of COL2A1, demonstrating the potential for promoting collagen synthesis. Post-treatment of both antioxidant supplements inhibited TNF- $\alpha$ and reduced MMP-1, while pre-treatment did not (Figure 4). Our results suggested that post-treatment of OA-like chondrocytes with vitamin E and resveratrol can more effectively reduce the level of inflammation than pre-treatment as well as single treatment. However, animal verification and clinical investigation will be required to verify the clinical applications of vitamin $\mathrm{E}$ and resveratrol for OA treatment.

\section{Conclusions}

We investigated the role of vitamin $\mathrm{E}$ and resveratrol on the level of oxygen-derived free radicals and the expression of inflammatory genes. Both vitamin $\mathrm{E}$ and resveratrol reduced the level of free radicals that were induced by $\mathrm{H}_{2} \mathrm{O}_{2}$. Single treatment with either vitamin $\mathrm{E}$ or resveratrol reduced the expression of IL- $1 \beta$ and TNF- $\alpha$. A combination of vitamin $E$ and resveratrol not only inhibited the expression of IL-1 $\beta$ and TNF- $\alpha$ but also promoted the expression of COL2A1. The cell viability results demonstrated the biocompatibility of both antioxidant supplements, implying their potential application for reducing inflammation in $\mathrm{OA}$.

Author Contributions: Conceptualization, C.-Y.S., Y.L., and H.-W.F.; methodology, C.-H.F.; validation, C.-Y.S. and C.-H.F.; formal analysis, C.-Y.S., Y.L., and C.-H.F.; investigation, C.-H.F. and H.-W.F.; data curation, C.-Y.S., Y.L., and C.-H.F.; writing-original draft preparation, C.-Y.S.; writingreview and editing, Y.L. and H.-W.F. All authors have read and agreed to the published version of the manuscript.

Funding: This research received no external funding.

Institutional Review Board Statement: Not applicable.

Informed Consent Statement: Not applicable.

Data Availability Statement: The data presented in this study are available on request from the corresponding author.

Acknowledgments: This work was supported by the Ministry of Science and Technology (MOST), Taiwan under grant number 107-2221-E-027-039-MY3, and the National Taipei University of TechnologyShenzhen University Joint Research Program (NTUT-SZU-107-05).

Conflicts of Interest: The authors declare no conflict of interest.

\section{References}

1. Grover, A.K.; Samson, S.E. Benefits of antioxidant supplements for knee osteoarthritis: Rationale and reality. Nutr. J. 2016, 15, 1. [CrossRef] [PubMed]

2. Adatia, A.; Rainsford, K.D.; Kean, W.F. Osteoarthritis of the knee and hip. Part 2: Therapy with ibuprofen and a review of clinical trials. J. Pharm. Pharmacol. 2012, 64, 626-636. [CrossRef] [PubMed]

3. Juhl, C.; Christensen, R.; Roos, E.M.; Zhang, W.; Lund, H. Impact of exercise type and dose on pain and disability in knee osteoarthritis: A systematic review and meta-regression analysis of randomized controlled trials. Arthritis Rheumatol. 2014, 66, 622-636. [CrossRef] [PubMed] 
4. McCarberg, B.; Tenzer, P. Complexities in the pharmacologic management of osteoarthritis pain. Curr. Med. Res. Opin. 2013, 29, 539-548. [CrossRef] [PubMed]

5. Wojdasiewicz, P.; Poniatowski, L.A.; Szukiewicz, D. The role of inflammatory and anti-inflammatory cytokines in the pathogenesis of osteoarthritis. Mediat. Inflamm. 2014, 2014, 561459. [CrossRef] [PubMed]

6. Melchiorri, C.; Meliconi, R.; Frizziero, L.; Silvestri, T.; Pulsatelli, L.; Mazzetti, I.; Borzi, R.M.; Uguccioni, M.; Facchini, A. Enhanced and coordinated in vivo expression of inflammatory cytokines and nitric oxide synthase by chondrocytes from patients with osteoarthritis. Arthritis Rheum. 1998, 41, 2165-2174. [CrossRef]

7. van de Loo, F.A.; Joosten, L.A.; van Lent, P.L.; Arntz, O.J.; van den Berg, W.B. Role of interleukin-1, tumor necrosis factor alpha, and interleukin-6 in cartilage proteoglycan metabolism and destruction. Effect of in situ blocking in murine antigen-and zymosan-induced arthritis. Arthritis Rheum. 1995, 38, 164-172.

8. Shakibaei, M.; Schulze-Tanzil, G.; John, T.; Mobasheri, A. Curcumin protects human chondrocytes from il-11beta-induced inhibition of collagen type ii and beta1-integrin expression and activation of caspase-3: An immunomorphological study. Ann. Anat. 2005, 187, 487-497. [CrossRef]

9. Stove, J.; Huch, K.; Gunther, K.P.; Scharf, H.P. Interleukin-1beta induces different gene expression of stromelysin, aggrecan and tumor-necrosis-factor-stimulated gene 6 in human osteoarthritic chondrocytes in vitro. Pathobiology 2000, 68, 144-149. [CrossRef]

10. Vincenti, M.P.; Brinckerhoff, C.E. Transcriptional regulation of collagenase (mmp-1, mmp-13) genes in arthritis: Integration of complex signaling pathways for the recruitment of gene-specific transcription factors. Arthritis Res. 2002, 4, 157-164. [CrossRef]

11. Fridovich, I. Oxygen: How do we stand it? Med. Princ. Pract. 2013, 22, 131-137. [CrossRef] [PubMed]

12. Walia, M.; Kwan, C.Y.; Grover, A.K. Effects of free radicals on coronary artery. Med. Princ. Pract. 2003, 12, 1-9. [CrossRef] [PubMed]

13. Altindag, O.; Erel, O.; Aksoy, N.; Selek, S.; Celik, H.; Karaoglanoglu, M. Increased oxidative stress and its relation with collagen metabolism in knee osteoarthritis. Rheumatol. Int. 2007, 27, 339-344. [CrossRef] [PubMed]

14. Sutipornpalangkul, W.; Morales, N.P.; Charoencholvanich, K.; Harnroongroj, T. Lipid peroxidation, glutathione, vitamin e, and antioxidant enzymes in synovial fluid from patients with osteoarthritis. Int. J. Rheum. Dis. 2009, 12, 324-328. [CrossRef] [PubMed]

15. Chen, Y.C.; Chang, Y.W.; Tan, K.P.; Shen, Y.S.; Wang, Y.H.; Chang, C.H. Can mesenchymal stem cells and their conditioned medium assist inflammatory chondrocytes recovery? PLoS ONE 2018, 13, e0205563. [CrossRef] [PubMed]

16. Gao, G.; Ding, H.; Zhuang, C.; Fan, W. Effects of hesperidin on $\mathrm{H}_{2} \mathrm{O}_{2}$-treated chondrocytes and cartilage in a rat osteoarthritis model. Med. Sci. Monit. 2018, 24, 9177-9186. [CrossRef]

17. Hochberg, M.C. New directions in symptomatic therapy for patients with osteoarthritis and rheumatoid arthritis. Semin. Arthritis Rheum. 2002, 32, 4-14. [CrossRef]

18. Crofford, L.J. Use of nsaids in treating patients with arthritis. Arthritis Res. Ther. 2013, 15, S2. [CrossRef]

19. Dworski, R.; Han, W.; Blackwell, T.S.; Hoskins, A.; Freeman, M.L. Vitamin e prevents nrf2 suppression by allergens in asthmatic alveolar macrophages in vivo. Free Radic. Biol. Med. 2011, 51, 516-521. [CrossRef]

20. Peh, H.Y.; Tan, W.S.; Liao, W.; Wong, W.S. Vitamin e therapy beyond cancer: Tocopherol versus tocotrienol. Pharmacol. Ther. 2016, 162, 152-169. [CrossRef]

21. Bhatti, F.U.; Mehmood, A.; Wajid, N.; Rauf, M.; Khan, S.N.; Riazuddin, S. Vitamin e protects chondrocytes against hydrogen peroxide-induced oxidative stress in vitro. Inflamm. Res. 2013, 62, 781-789. [CrossRef] [PubMed]

22. Csaki, C.; Keshishzadeh, N.; Fischer, K.; Shakibaei, M. Regulation of inflammation signalling by resveratrol in human chondrocytes in vitro. Biochem. Pharmacol. 2008, 75, 677-687. [CrossRef] [PubMed]

23. Shakibaei, M.; Csaki, C.; Nebrich, S.; Mobasheri, A. Resveratrol suppresses interleukin-1beta-induced inflammatory signaling and apoptosis in human articular chondrocytes: Potential for use as a novel nutraceutical for the treatment of osteoarthritis. Biochem. Pharmacol. 2008, 76, 1426-1439. [CrossRef] [PubMed]

24. Shakibaei, M.; John, T.; Seifarth, C.; Mobasheri, A. Resveratrol inhibits il-1 beta-induced stimulation of caspase-3 and cleavage of parp in human articular chondrocytes in vitro. Ann. N.Y. Acad. Sci. 2007, 1095, 554-563. [CrossRef]

25. Elmali, N.; Esenkaya, I.; Harma, A.; Ertem, K.; Turkoz, Y.; Mizrak, B. Effect of resveratrol in experimental osteoarthritis in rabbits. Inflamm. Res. 2005, 54, 158-162. [CrossRef]

26. Deng, Z.; Li, Y.; Liu, H.; Xiao, S.; Li, L.; Tian, J.; Cheng, C.; Zhang, G.; Zhang, F. The role of sirtuin 1 and its activator, resveratrol in osteoarthritis. Biosci. Rep. 2019, 39. [CrossRef]

27. Lei, M.; Wang, J.G.; Xiao, D.M.; Fan, M.; Wang, D.P.; Xiong, J.Y.; Chen, Y.; Ding, Y.; Liu, S.L. Resveratrol inhibits interleukin 1beta-mediated inducible nitric oxide synthase expression in articular chondrocytes by activating sirt1 and thereby suppressing nuclear factor-kappab activity. Eur. J. Pharmacol. 2012, 674, 73-79. [CrossRef]

28. Moon, M.H.; Jeong, J.K.; Lee, Y.J.; Seol, J.W.; Jackson, C.J.; Park, S.Y. Sirt1, a class iii histone deacetylase, regulates tnf-alphainduced inflammation in human chondrocytes. Osteoarthr. Cartil. 2013, 21, 470-480. [CrossRef] 